\title{
Abdias do Nascimento y Manuel Zapata Olivella: intelectuales del siglo XX en el sendero de la discursividad ancestral yoruba y bantú Denilson Lima Santos ${ }^{1}$
}

\section{Comencemos una charla}

La literatura afrolatinoamericana es una buena herramienta para repensar la presencia de las culturas yoruba y bantú ${ }^{2}$ en las sociedades de América Latina. En este sentido planteamos que las tradiciones africanas aparecen reelaboradas en la escritura literaria con propósitos políticos particulares, en especial como parte del reconocimiento del aporte africano a las naciones del continente. La herencia africana ocupa un lugar de relieve en la religiosidad, la culinaria, el deporte $\mathrm{y}$, por supuesto, en la literatura. Ejemplo de esta singular manera de entender a América Latina es la obra Sortilégio II: mistério negro de Zumbi redivivo (1979), de Abdias do Nascimento (Franca, 1914 - Rio de Janeiro, 2011) y Changó, el gran putas (1983), de Manuel Zapata Olivella (Lorica, 1920 Bogotá, 2004). Tales obras y autores recrean las tradiciones yorubas y bantúes, partiendo de un proyecto estético con fines políticos. Tanto el uno como el otro llegaron a ser figuras políticas de primer orden en sus respectivos países.

Para describir a los autores y sus obras, anteriormente citados, proponemos dos categorías: la intelectualidad afrolatinoamericana y la discursividad literaria de la ancestralidad. Se podría pensar, en principio, en tres posibilidades de comprensión del intelectual afro: la primera el que conserva la lengua africana, como en el palenque San

\footnotetext{
${ }^{1}$ Estudiante del Programa de Doctorado en Literatura de la Universidad de Antioquia (U de A), Medellín, Colombia. Becado por Capes fundación. Correo electrónico: denilsonlimas@ gmail.com

${ }^{2}$ Aclaramos que hay una distinción entre las lenguas bantúes y yorubas, aquí seguimos las huellas de la lingüísta Yeda Pessoa de Castro (s.d.): "A região banto compreende um grupo de 300 línguas muito semelhantes, faladas em 21 países: Camarões, Chade, República Centro-Africana, Guiné Equatorial, Gabão, Angola, Namíbia, República Popular do Congo (Congo-Brazzaville), República Democrática do Congo (RDC ou Congo-Kinshasa), Burundi, Ruanda, Uganda, Tanzânia, Quênia, Malavi, Zâmbia, Zimbábue, Botsuana, Lesoto, Moçambique, África do Sul” (s.d., p. 3). Ya en relación a la lengua yoruba: "O iorubá é uma língua única, constituída por um grupo de falares regionais concentrados no sudoeste da Nigéria (ijexá, oió, ifé, ondô, etc.) e no antigo Reino de Queto (Ketu), hoje, no Benim, onde é chamada de nagô, denominação pela qual os iorubás ficaram tradicionalmente conhecidos no Brasil" (s.d., p. 3). En suma, bantú es un conjunto de lenguas y yoruba es una lengua con dialectos distintos, variando a cada región.
} 
Basilio en Colombia, en las religiones de matriz africana en Cuba, Brasil y Haití. La segunda es aquél que está ligado a la tradición oral, es decir, no escribe, sólo utiliza el lenguaje oral: las mujeres que cantan en las religiones, las que hacen rezas, los que guardan la espiritualidad y ritualidad religiosas. La tercera - y la cual vamos a nos ocupar en este ensayo - es aquél que se apropió de la escritura del amo y crea una estética en contra la hegemonía.

En cuanto a la ancestralidad, para entenderla en la literatura afro, pensamos la escritura literaria de Abdias do Nascimento y Manuel Zapata Olivella a partir del planteamiento de Eduardo Assis Duarte (2012) que establece parámetros para la literatura afro (temática, autoría, punto de vista, lenguaje y público) que están relacionados con el sujeto negro o mestizo dentro del ámbito de la discursividad literaria. Esta es comprendida como la recuperación de las tradiciones yoruba y bantú por medio de la escritura. En otros términos, los intelectuales afrolatinos tejen en sus obras otras voces, es decir, una estética discursiva y política distinta de la impuesta por el orden vigente. A partir de ahí, el discurso literario tanto del afrobrasileño como del afrocolombiano está preñado de sus experiencias como aportes a una escritura colectiva. De esta manera, se comprende en este ensayo la reinvención de las tradiciones yoruba y bantú, realizada por los intelectuales en la escritura de sus obras, como una discursividad literaria de los ancestrales.

\section{Autores y obras en la escena latinoamericana}

El paulista de Franca, Abdias do Nascimento, hijo de Georgina Ferreira do Nascimento (ama de casa y modista) y José Ferreira do Nascimento (zapatero), ocupó de la defensa de la cultura e igualdad para las poblaciones afrobrasileñas. Su participación en la sociedad fue importante, puesto que reflexionó sobre la actividad y la cuestión del negro en Brasil. También participó de la vida política y cultural. Fundó en 1944 el Teatro Experimental Negro, fue miembro de la Frente Negra Brasileña, movimiento negro extinto por la dictadura del gobierno de Getulio Vargas en la década de 1930. También fue diputado federal (1983-1987) y senador de la república (1997-1999). Además de eso, en 1978 fundó el Movimiento Negro Unificado y propuso con éxito el 20 de noviembre como día de la conciencia negra en la ciudad de São Paulo. Es importante mencionar que hay relevantes trabajos sobre la obra del 
intelectual afro-brasileño, de las cuales se puede citar: Abdias do Nascimento 90 anos (2004), de Elisa Larkin Nascimento; el libro de Celso Uchoa Cavalcanti: Abdias do Nascimento. Memórias do Exílio (1976), que hace un relato de la vida y obra del brasileño al plantear sobre las cuestiones de una literatura negra producida bajo condiciones de resistencia. Otra obra, no menos importante, es la tesis doctoral de Rosemere Ferreira da Silva, Trajetórias de dois intelectuais negros brasileiros: Abdias Nascimento e Milton Santos (2010), la cual hay una comparación entre la formación intelectual de Abdias do Nascimento y Milton Santos (1926-2001) y la trayectoria de ambos dentro y fuera de Brasil.

De igual manera, la obra de Nascimento compreende un extenso listado de publicaciones, entre las cuales podemos mencionar a O Griot e as Muralhas (2006); Quilombo: Edição em fac-símile do jornal dirigido por Abdias do Nascimento (2003 [1948-1950]); O quilombismo (2002[1980]); O Brasil na Mira do Pan-Africanismo (2002); Orixás: os Deuses Vivos da África (1995) y Sortilégio II: mistério negro de Zumbi redivivo (1979 [1957]), obra de la que nos ocuparemos en este ensayo.

Sobre la pieza para teatro Sortilégio II se sabe que fue presentada al público en agosto de 1957. En la composición de los personajes ya se denota un sentido contrario a lo que se podía ver en la dramaturgia brasileña de aquella época. En las acotaciones de la obra el autor deja claro que todos los personajes no sólo son negros, con voz propia, sino que además portan una estética proveniente de las culturas yoruba y bantú. Son Filhas de santo (iniciados en los rituales de la religión afrobrasileña), Iyalorixá o Babalorixá (sacerdotisa o sacerdote responsable por el liderazgo de la comunidad religiosa), Doutor Emanuel (negro, abogado, personaje principal), Ifigênia (mujer negra, ex novia de Emanuel), Margarida (esposa de Emanuel, ella es el único personaje blanco), Teoria das Yaôs y Teoria dos Omolus (iniciados en la ritualidad ancestral afrobrasileña, cada oricha tiene un arquetipo y esto se refleja en sus hijos). Otro dato importante es que la pieza es de un solo acto, las escenas cambian y el escenario es reconfigurado con ayuda de luces y permuta del lugar, como propone el autor en las acotaciones escénicas.

Sortilégio II es la denuncia contra el racismo de una sociedad supuestamente moderna que aún rechaza la estética del negro por considerar que la eurocéntrica es la que brinda la normatividad a la nación. Como afirma Philip Zwerling en el ensayo “The Political Agenda for Theatricalizing Religion in Shango de Ima and Sortilege II: 
Zumbi Returns" (2004, p. 8), Abdias do Nascimento y, por supuesto, su obra representan "a continuing color-conscious society". Al comparar Sartilégio II y Shangó de Ima (del cubano Pepe Carril), Zwerling (2004) postula que las obras teatrales de los autores latinoamericanos están ubicadas bajo las cuestiones políticas, como las relaciones raciales, además de representar la recuperación de la tradición yoruba en las sociedades brasileña y cubana. De manera general, se puede afirmar que do Nascimento recupera la consciencia negra y va más allá de un proyecto puramente político-sociológico. Su obra se inserta en una discursividad de la tradición yoruba, es decir, recupera la estética afro en la escritura con el propósito de demonstrar no solo el conflicto social sino el discursivo.

De hecho el proyecto de Sortilégio II es el resultado de las múltiples luchas políticas de Nascimento en especial las que libró en su periódico Quilombo (1948-1950), lo cual es absolutamente visible su preocupación por mostrar al negro en su belleza y su participación social. Para tal sociedad el negro solamente servía para hacer servicios pesados, ser sometido al "amo" y responder mansamente: "Não senhor... sim senhor..." (Nascimento, 1979, p. 77). El drama en la obra de Abdias do Nascimento es del personaje Emanuel que sufre racismo desde su niñez, pues lo llaman despectivamente "tição" (Nascimento, 1979, p. 68), es decir, tiznado o demasiado negro. A pesar de ello, por el deseo de saber, el niño crece, estudia y se gradúa en Derecho, ejerciendo la profesión de abogado de los blancos. En su trayectoria Emauel reniega de Exu, quien en la cultura yoruba es la divinidad que ejerce el papel de intermediario entre los humanos y los orichas. El doctor hace lo mismo con Obatalá, divinidad que es el señor de la creación en tradición yoruba. La vida del abogado es un intento de olvidar sus raíces ancestrales, pero al fin él acepta su origen afro. Además de eso, el ambiente de la pieza es el terreiro $^{3}$ donde se hacen los rituales de la religión candomblé. Este espacio en la obra permite una relectura de las tradiciones africanas y construye la ancestralidad en términos literarios para explicar las relaciones del ser humano con el mundo circundante y la presencia viva del mundo africano en América.

El loriquero Manuel Zapata Olivella, hijo de Edelmira Olivella (ama de casa) y Antonio María Zapata Vásquez (profesor), es considerado un

\footnotetext{
${ }^{3}$ Término bantú y yoruba que, en español, correspondería a la finca.
} 
relevante autor por exponer en sus obras una forma de las identidades negras, teniendo en cuenta el encuentro del afro con el mestizo y el indígena. Desde su juventud empezó a escribir en el periódico El Fígaro, en las revistas Estampa de Bogotá, Cromos, Sábado y Suplemento Literario de El Tiempo. Además de eso, el autor negro colombiano tuvo una extensa creatividad literaria, entre las que cabe destacar Tierra mojada (1947) y Calle 10 (1960) ya que el autor no se ocupó sólo de la temática afro. La problemática mitificada de los negros de América es abordada en Chambacú, corral de negros (1963), en Chimá nace un santo (1963) y en Changó, el gran putas (1983), obra que hará parte del análisis en este ensayo. Las obras del intelectual afrocolombiano ganó una notoriedad en la primera década del siglo XXI en la academia, puesto que hay muchas investigaciones que esbozan un perfil tanto de su biografía como su producción literaria. Para ello podemos citar: La evolución literaria de Manuel Zapata Olivella: Testimonio, autobiografia y novela (2008), de Sandra Alzate; Manuel Zapata Olivella, caminante de la literatura y cultura (2001), de José Luis Gonzales Garces; La trayectoria novelística de Manuel Zapata Olivella: de la opresión a la liberación, en Ensayos de literatura colombiana (1985), de Marvin Lewis; entre otros autores que hacen un estudio crítico de la obra de Zapata Olivella.

En la novela Changó, el gran putas hay un tejido narrativo que va desde los orígenes mitológicos de los ancestros en África hasta las luchas por los derechos civiles en los Estados Unidos. Las voces de los personajes trazan una línea de la historia de la tradición africana, marcada en el Nuevo Mundo por la esclavitud. Zapata rehace el mundo africano antes y después de la trata negrera durante el colonialismo europeo de las Américas. La novela también recrea una nueva episteme en la narrativa cuando incorpora las tradiciones africanas especialmente los pueblos bantúes y yorubas, entre otros que fueran traídos a estas tierras. Así, para elaborar tal mundo, el escritor afrocolombiano se apropia del idioma del colonizador para minarlo, desmontarlo e insertar otra estética, es decir, otros temas y otras musicalidades. En la obra, no hay duda que Zapta Olivella "literally reconstructs the social hierarchical order" (Tillis, 2005, p. 19) no solo en sentido de papeles sociales sino de la reinvención de la religiosidad yoruba y bantú en un contextos de esclavismo y resistencia.

Así, la narrativa de Zapata es la invención de la cultura de origen africano dentro de un texto literario. Para dar un ejemplo, al lado de la 
religiosidad católica, en la época de Pedro Claver, aparece la música ritual de los afro: "[p]or la mañana se oyeron los redobles del tambor, muy distintos al de los brujos que escandalizan por las noches" (Zapata, 2010, p. 175).

De hecho, la narración de Zapata Olivella teje una escritura insertada de expresiones y tradiciones orales que inscriben una relectura de las huellas de la oralidad de los pueblos africanos traídos a América Latina. Eso es posible constatar especialmente cuando leemos en la novela expresiones que indican en la escritura la vigencia de elementos culturales africanos. Así, por ejemplo, hay "un vodú escondido en la kora" (Zapata, 2010, p. 7), es decir, en un instrumento de cuerda africano. O los "Ancestros [son] sombra de mis mayores" (Zapata, 2010, p. 8). Este principio narrativo africano indica que la voz de los mayores que cuentan es importante para la formación de los jóvenes que la escuchan. Por eso en la novela los personajes construyen una continuidad discursiva que va de Ngafua, Nagó, Benkos hasta Agnes Brown.

Mario Aguiar Ch. afirma que la novela Changó, el gran putas es un "mundo abiertamente identitario que simultáneamente conserva asomos de un contenido marcado por las luchas sociales que han embargado a los pueblos tercermundistas del siglo XX" (2004, p. 1). Y más allá de la lectura sociológica, la obra de Zapata Olivella es considerada el culmen entre todas las otras producciones literarias y antropológicas, como afirma Jose Antonio Caicedo Ortiz (2013). Además de esto, un dato importante es que en 1974 el escritor afro colombiano asistió al coloquio Diálogos de la Negritud y la América Latina, Dakar (Senegal); de ahí surge su novela Changó, el gran putas "que de acuerdo a su autobiografía fue producto del contacto con sus ancestros" (Caicedo, 2013, p. 309). De esa manera, por su importancia en la literatura latinoamericana, por ejercer una "magnitud y complejidad narrativa, esta novela le mereció en Brasil en 1985 el Premio Literario Francisco Matarazzo Sobrino" (Caicedo, 2013, p. 313).

Por lo anterior es importante emprender un estudio analítico de estas dos obras, pues de esta forma se podrá explicar un capítulo largamente aplazado en los estudios de la intelectualidad afro que hace referencia a los modos por los cuales los escritores afro en Brasil y en Colombia lograron paralelamente preservar y recrear a través de la literatura las tradiciones yorubas y bantúes. Además, este estudio permitiría entender los procesos semejantes y distintos de la intelectualidad afro en los dos países. 
En Brasil, segundo Maria Alice Rezende de Carvalho, el período colonial fue "el ambiente de proyección de un gran número de intelectuales negros y mulatos - a diferencia de lo que ocurrió durante la república, cuando este segmento conoció un retraimiento notable" (2008, p. 312). La autora expone como en la historia intelectual del afro en el país brasileño hubo un cambio en el período de la República. Pese a que hombres de letras como André Pinto Rebouças (1838-1898), João da Cruz e Sousa (1861-1898), Afonso Henrique de Lima Barreto (18811922) alcanzasen la educación formal, tuvieron sus caminos como intelectual atrapados en el estigma del color.

En Colombia, de acuerdo a las postulaciones de Jose Antonio Caicedo Ortiz, el pensamiento afro se despunta en el siglo XX; humanistas como Jorge Artel (1909-1994), Arnoldo Palacios (1924- ), Alfredo Vanín (1950- ), entre otros, son ligados por la memoria étnica que les da una "conciencia de un pensamiento hecho contra el olvido afrodescendiente de la nación mestiza en siglo XX" (Caicedo, 2013, p. 35).

El flujo de posibilidades de creación de intelectuales afrodescendientes en Brasil en los tiempos de la colonia e imperio fue más intenso, se puede ver, por ejemplo, poetas como Domingos Caldas Barbosa (1738-1800), Manauel Inácio da Silva Alvarenga (1749-1814), Laurindo José da Silva Rabelo (1826-1864), Luiz Gonzaga Pinto da Gama (1830-1882) y Antônio Gonçalves Dias (1823-1864). Otro dato importante fue la gran cantidad de esclavos musulmanes que sabían leer y escribir en árabe e intentaron una rebelión entre 24 y 25 de enero de 1835, hecho conocido como la rebelión malé (nombre dados a los esclavos musulmanes en Bahía, Brasil).

Ya en Colombia en siglo XIX surge Candelario Obeso (1849-1884) que inserta en su obra el cotidiano y el folklor de estas tierras. Lo que se percibe es que en la modernidad - sobre todo en el según cuarto del siglo XX en los países latinoamericanos - hay un despertar de la conciencia $y$, por supuesto, publicaciones de autores afros. A partir de este período los escritores negros y mestizos visibilizan en sus obras los aportes de las tradiciones venidas de África.

\section{La presencia yoruba y bantú en el intelectual afro-latinoamericano: un proceso en construcción}


Sortilégio II y Changó evidencian la presencia yoruba y bantú, además de ofrecer elementos para una compresión de la intelectualidad afro-latinoamericana. De hecho, el intelectual afro es comprendido aquí como el que se apropia del sistema esclavista de la lengua europea para subvertir, por medio de la discursividad literaria, la cultura hegemónica, pero, para eso, recupera elementos de las tradiciones africanas: el léxico, estructuras narrativas, temas, adaptaciones religiosas, formas de pensamientos de la huella africana ${ }^{4}$ en América.

En este sentido es que Abdias do Nascimento hace el uso de otros signos sistemáticos para escribir su pieza para teatro, Sortilégio II: los orichas, los babalorixás o Ialorixás que son sacerdotes religiosos, Yaôs, es decir, los iniciados en los rituales ancestrales; además del conflicto racial en Brasil. Nascimento usa el modelo estructural del drama de origen griego y lo subvierte en la escritura. Un ejemplo de eso es el coro que aparece como “teoria da Yaôs" y "teoria dos Omolus" (Nascimento, 1979, p. 39).

Igualmente, de manera híbrida, o mejor: triétnica, Manuel Zapata Olivella utiliza, en la novela Changó, el gran putas, la estructura clásica de la épica, cuando comienza su libro con el poema sobre los orígenes de los dioses africanos: "(La kora ríe/ lloraba la kora, / sus cuerdas hermanas/ narrarán un solo canto/ la historia de Nagó/ el trágico viaje del Muntu/ al continente exilio de Changó)." (2010, p. 41). Con esta apertura, el afrocolombiano cambia la tradición de canto a los dioses griegos por los dioses negro-africanos, además de insertar la kora, instrumento musical, como una de las muchas voces que expresan las tradiciones originadas en el otro lado del Atlántico. En suma, tanto Zapata Olivella como do Nascimento están construyendo una nueva forma de novela y teatro. La estructura de base es la forma literaria de tradición europea, pero el contenido, lenguaje y signos, entre otros elementos están preñados de voces africanas reactualizadas por los dos intelectuales que toman "el lenguaje para denunciar los horrores con la belleza de la palabra” (Caicedo, 2013, p. 33).

\footnotetext{
${ }^{4}$ El término huella africana o huellas de africanías se puede emplear para explicar el proceso estético seguido por los pueblos afro en América, pues comprende la "dinámica sociocultural de innovación, creatividad y transformación, sin negar la participación de supervivencias. Y entre éstas no solamente las africanas, sino también las europeas y las aborígenes" (Friedemann, 1992, p. 545). Entonces, las huellas africanas son las expresiones, gestualidad, creatividad, tecnología comunicativas, etc. que se transculturaron en las sociedades latinoamericanas y entraron en contacto con otras maneras de saber y de existir.
} 
Para aproximarse más a cuestiones de la intelectualidad afro propuesta por Manuel Zapata Olivella, se puede señalar que la novela Changó, el gran putas está dividida en cinco partes. Cada parte presenta la ancestralidad como el hilo que liga a los afros desde África hasta la contemporaneidad, construyendo una representación de una inteligencia negro-africana en la diáspora.

En la primera parte "Los orígenes", se encuentra el origen mítico de los negros africanos y como la trata negrera dispersó los hijos de Changó por el mundo. Zapata se aproxima de la genealogía judaica cristiana con tonalidades griegas para exponer el surgimiento de los dioses africanos y su influjo sobre los humanos. El primero "La tierra de los ancestros" aparece la figura del africano como traficante negrero, personificada en la personaje Ezili que transaba a los negros capturados en África con los europeos y al mismo tiempo desconfiaba del blanco. En el apartado "La alargada huella entre dos mundos" el escritor evidencia una distancia física entre África y América, además de exponer cómo la raza blanca y la raza negra ven los sucesos circundantes.

En la segunda parte, "El Muntu americano", Zapata demuestra cómo funciona la esclavitud en América, sobre todo cuestiones tales la experiencia esclavista americana bajo el potentado español, portugués, francés e inglés. Él inserta un tiempo histórico (en sentido más narratológico) y alza mano a personajes importantes en la lucha por libertad en la América negra, son ellos, Benkos Biojo, François Mackandal y Nat Turner. Hay un resalto en el personaje Benkos Biojos que nace bajo la protección del Oricha Elegba y trae en su cuerpo el signo de dos serpientes devorándose, pues es el símbolo que indica el líder palenque como escogido para la lucha libertaria de los negros esclavizados. De ahí, él es lo que nombramos aquí de intelectual libertario e integrador:

El rey Benkos la lleva del brazo, nadie detrás del otro, la luna y el sol por primera vez juntos. Los príncipes, los generales, las damas de compañía, el antiguo Imperio de Oyo renacido y Benkos su nuevo emperador. Era el ñgola, el monotapa con la marcha de sus mil elefantes y el bullicio y la danza de mil congos, mil ardás, mil angolas, reunidos por las voces de mil tambores (Zapata, 2010, p. 201).

Nótese que la reactualización del personaje histórico palenque en la escritura de Zapata Olivella establece una integración de origen y 
tradición africanos: "Imperio de Oyo" es de la tradición Yoruba; "ñgola, monotapa" son de la tradición bantú y además de esto la expresión "congos" se refiere a otra etnia africana. Las tradiciones de origen afro son inventadas en varios personajes. El autor dialoga con la historia para dimensionar la totalidad del Muntu, es decir, humanidad. Se puede percibir que el afrocolombiano requiere en la estética textual un estatuto político, una vez que estas identidades africanas ahora están bajo las mismas condiciones: en la esclavitud y su búsqueda por la liberación.

Es importante evidenciar que no hay una voz individual de origen africano sino una pluralidad de voces o heterogeneidades de los afros en América y el autor dejará claro eso en toda su narrativa. Es importante ver que en esta parte de la obra hay una demonstración que el colonizador usa el sometimiento y poder cultural para borrar la cultura, religiosidad y lengua de los esclavizados, sin embargo, los dominados utilizan el mundo mítico-religioso para interpretar su mundo externo y sus dramas personales, no permitiendo que su cultura sea anulada. De esa manera, los negros esclavizados hacen un esfuerzo para preservar su identidad cultural de origen africano que torna un "devenir" afroamericano.

Ya en la tercera parte, "La rebelión de los vodús", el escritor colombiano establece como el héroe a Mackandal, el líder haitiano que es importante en la lucha de la liberación en Haití. Siguiendo la narrativa, aparecen los símbolos míticos, es decir, personajes que surgen como ancestros Ogún Ngafúa y Ogún Nagó ${ }^{5}$ reiterado en las voces de otros personajes históricos como Toussaint L' Ouverture, Dessalines y el emblemático Henri Chritophe, el primero emperador negro en América.

Así entre peleas libertarias y reconstrucciones de la identidad cultural afro, podemos observar una intelectualidad afrolatinoamericana, vista en la obra por dos lentes: la primera es la propagación de las proezas que los líderes negros haitianos hicieron para liberar su nación y la segunda son los conflictos internos que hubo

\footnotetext{
${ }^{5}$ Ngafúa es el primero hijo de Changó que surge y cuenta la saga de los dioses, después él transmite el conocimiento a Nagó, el primero hijo de Changó escogido aún allá en África para quemar el barco de los blancos y ahondarlo, así comienza la lucha por liberación. Más adelante en la novela ellos se transforman en mensajeros y protectores de otros personajes que siguen la saga por la libertad. Bajo el signo de Ogún, ellos son los ancestrales que orientan a los ekobios (compañeros). Informamos también que nagó o nagô en Brasil es el gentilicio para los africanos originarios de Keto, África, y que iniciaron los cultos a los ancestros en Bahia. De ahí, nagô y yoruba son términos sinónimos.
} 
en la revolución, es decir, son héroes, forman una tradición de pensamiento y lucha política negra, pero serán vistos en el futuro también por sus debilidades. En efecto, Zapata Olivella utiliza estos elementos en la composición de los personajes, dando a la narrativa un movimiento del interior para el exterior, proponiendo una inteligencia que se construye bajo las contradicciones humanas. Aunque con sus fragilidades, los personajes logran, más bien, Mackandal consigue con su oralidad, conocimiento y persuasión convencer a los esclavos a envenenar el agua del amo y hacer la revolución haitiana. De esa manera, Mackandal no muere nunca, puesto que él está en la memoria de lucha de los ekobios, esto es, cofrade y, igual modo, él será el aliento de las futuras batallas por la libertad.

En la cuarta parte, "Las sangres encontradas", la escritura prosigue y recrea otras formas de intelectualidad afro, digamos que con el alargamiento del pensamiento ancestral y la trietnicidad, una vez que otros personajes históricos, los criollos, mestizos y zambos ya absorben el mundo mítico de origen africano e lo inserta en la cultura hegemónica del colonizador. La libertad de las cadenas de la Loba Blanca se rehace en la narrativa del escritor colombiano en las luchas independentistas en varias regiones de Caribe y América Latina.

Con tonos de epopeya, aparecen líderes políticos e insignes de la independencia como Simón Bolívar, José Prudencio Padilla, Antonio Maceo, José María Morelos y el escultor brasileño Aleijadinho. Es importante observar como la africanía es rescrita por Zapata Olivella en el personaje, a saber el escultor brasileño. La estética negra en sus esculturas es entablada en la novela como continuidad de la ancestralidad, es decir, hay una línea continua que aparece cuando preconiza el ancestro: "Soy Kanuri Mai, nunca apartado de ti. Me esculpirás en los rostros de tus profetas, en las carnes desgarradas del buen Señor de Matozinhos, allí donde quiera que tu mano sin dedos dejó la huella de tu espíritu" (Zapata, 2010, p. 326). La ancestralidad se reintegra a la formación étnica americana, haciendo el movimiento de intelectualidad subversiva en relación a estética hegemónica. De ahí, el africano Kanuri Mai resurge en la narrativa para establecer la ligación de la ancestralidad como reto estético, político y sobre todo, discursividad literaria. Todo esto es la hazaña que el escritor afro tiene de recrear por intermedio de la escritura un estilo en que las figuras del lenguaje, la mimesis "hacen posible la inmanente africanía en estas 
tierras, ya sea con las huellas evidentes de los objetos y las prácticas culturales, o con las sombras que la espiritualidad y la memoria proveen" (Caicedo, 2013, p. 33).

En "Los Ancestros combatientes", que es la quinta parte, hay una relectura, podemos decir así, de la esclavitud; aunque ella ya había terminado, dejó otras formas de opresión. Los capítulos son dedicados a narrar la lucha de los derechos civiles en Estados Unidos de América, de ahí personajes como Nat Tumer, Agnes Brown, Malcon X serán íconos de las particularidades del movimiento negro estadounidense. Zapata expone las persecuciones, injusticias sociales, las masacres y como nasce el intelectual negro consciente de una revolución.

Otro ejemplo de intelectual que aparece aquí es el que construye por la lucha la libertad y nuevos rumbos políticos: "No habrá un solo ekobio realmente libre en este país mientras persista la esclavitud. No olvides que en Haití solo se logró la libertad cuando los negros victoriosos pudieron fundar su propia república" (Zapata, 2010, p. 521). El personaje padre de Agnes Brown - la afromericana en el contexto de la libertad y derecho civil Norteamericano - desarrolla el papel de formar la hija y despertar en ella la conciencia ancestral para libertad. Tal vez, la relación intelectual aquí pueda ser comprendida como apropiación del saber.

La construcción de la intelectualidad en la narrativa de Zapata Olivella puede ser interpretada como una relación entre conocimiento y sociedad. Relación entre grupos sociales. Hay producciones mentales en los grupos sociales, como postula Karl Mannheim (1973). En efecto, el conocimiento ancestral reanuda en la figura de Agnes Brown, puesto que es convocada por Changó y ella posee el signo de las serpientes que se devoran en círculo, es decir, la marca de la escogida, a saber, la representante de aquellos que están bajo la opresión civil en EE.UU. A que me parece, la figura del intelectual afro aquí es emblemática para nuestra contemporaneidad. Primero es la mujer, según la consciencia colectiva.

Agnes es el símbolo de la inteligencia de la mujer negra, sobre todo en el contexto de una sociedad machista, de ideales blancos, eurocéntricos y que, a veces, el hombre negro absorbe el discurso hegemónico y oprime a la mujer negra. Así, por medio de la escritura de la ancestralidad, Zapata Olivella inserta en la estética literaria el papel de la intelectualidad visto por la mirada de la mujer. Agnes Brown nos hace pensar cómo y por qué el pensamiento afro necesita ser mirado con 
las herramientas culturales que le son propias para interpretar las voces heterogéneas de las comunidades negras.

En cuanto a la construcción de los personajes, Abdias do Nascimento, en la obra Sortolégio II, establece el drama como "uma forma de pensamento, um processo cognitivo, um método por meio do qual podemos traduzir conceitos abstratos em uma situação e descobrir suas consequências" (Esslin, 1986, p. 26). Con todo, el aspecto del conflicto racial e intelectual permea toda la pieza de teatro del autor brasileño. Ya presentamos anteriormente los personajes e indicamos que la obra está escrita en un solo acto, pero hay constantes cambios de escenarios para contextualizar el texto. De esa manera, se propone aquí llamar los cambios de escenas de movimientos. Entonces, el primer movimiento es el diálogo entre la sacerdotisa y las iniciadas lo cual hay la resonancia del saber africano personificada en la intelectualidad de la líder religiosa que interpreta para la comunidad el saber ancestral. Los personajes Filha I, II y III dialogan de manera que hacen con que el lector se entere del contexto del drama: "O destino está na cor. Ninguém foge impune do seu próprio destino" (Nascimento, 1979, p. 51). El drama del color es el leitmotiv para que concibamos como el intelectual afrobrasileño se ubica en una sociedad donde el privilegio es de aquellos que se acercan al modelo y patrón blancocéntrico. En el segundo movimiento aparece Emanuel huyendo de la policía pues él cometió el delito de matar a su esposa Margarida. Su refugio será el terreiro de candomblé y allá se pasará una larga escena donde Emanuel rehúsa su origen negro y la voz de su consciencia dialogará con las voces que representan las enseñanzas de la sacerdotisa, que no aparece, sólo se la escucha, y la voz de la Negra Velha (ícono de la madre que canta las canciones de cuna).

La construcción del personaje Emanuel proviene de los moldes del teatro africano, como afirma Nascimento en el prólogo de la pieza: "o ator africano é um ator congênito devido a sua extraordinária emotividade em busca de uma expressão" (1979, p. 21). Es posible que el hecho de esa expresividad emotiva sea el aporte de la oralidad o como afirma Schipper (1982), hoy en día el teatro de África refleja "a variety of societies, because of the simultaneous existence of so many different kinds of communities" (1982, p. 123). Tales variaciones en la comunidad están relacionadas a la tradición de una literatura oral, de performance de la voz, danza y etc. Todo esto son las "performances 
africanas tradicionales" (Schipper, 1982. p. 124, nuestra traducción) que se resalta en Sortilégio II lo que Abdias do Nascimento propone como invención de una escritura de la ancestralidad como delito bajo el lenguaje grafocéntrico occidental.

Otro importante movimiento del texto teatral de Abdias es el embate de Margarida (esposa), Emanuel e Ifigenia (exnovia). La relación social tiene dos enfoques: El primero es el negro que objetiva esposarse con una mujer blanca para tornarse socialmente acepto. El segundo enfoque es el de la mujer negra con el hombre blanco que representa el ícono de seducción, estableciendo la relación a un sometimiento sexual por parte de la mujer negra. En este diálogo la escritura gana los rasgos de los conflictos personales de los personajes y hace el movimiento hasta el exterior para expresar tanto el saber particular como el colectivo, pero no dejando de lado los embates raciales. De esa manera se percibe que el intelectual construido en el personaje Emanuel desde comienzo de la pieza es intolerante con su origen negro y absorbe como verdad absoluta la educación hegemónica que tuvo; además de presentar una sumisión a un modelo social impuesto por el grupo hegemónico.

En los diálogos con las Filhas de Santo y en los embates con Infigenia, Emanuel se depara con sus fantasmas en medio a tragos de la bebida ritualista de Exu, el marafu (aguardiente). El personaje está entre los dos mundos, más bien, entre la realidad racional y la mandinga que en este contexto se puede entender como embrujo:

Caô uma ova. Qual Exu qual nada, seu doutor. O que você quer agora é um bom charuto (apanha um charuto, acende, tira várias baforadas, julga ouvir um rumor, corre à ribanceira, espia, recua amedrontado; joga o charuto no chão, amassa-o com o pé) Serão eles? (aflito) na certa viram a brasa deste charuto excomungado. Oh!... preciso fugir... desaparecer! (Nascimento, 1979, p. 101)

Tal comportamiento de Emanuel puede ser leído como las contradicciones de su origen, el puro de Exu, que es elemento del ritual afrobrasileño, se contrapone con el juicio del personaje: "charuto excomungado", es decir, algo maligno. La crisis sigue cuando el personaje ruega a la esposa asesinada que le hable: "Fala, pelo amor de Deus! (aflito). Pelo amor de Deus, não. Por Exu... Por Oyá-Inhansan” (Nascimento, 1979, p. 105). Nuevamente el conflicto entre Dios, Exu y Oyá se presenta aquí como otra manera de pensar sobre la 
intelectualidad afro a partir de aquel que absorbe la cultura hegemónica y la concibe como superior, olvidándose de su origen.

Más allá de una categoría "social definida por su papel ideológico: [los intelectuales] son los productores directos de la esfera ideológica, los creadores de productos ideológicos-culturales" (Löwy, 1978, p. 17), el intelectual afro se conforma en la obra de Abdias do Nacimento en una zona de embates: cultura hegemónica de corte europea versus culturas afros. En verdad, como categoría social, los intelectuales no participan de la producción económica y esto les confiere una autonomía que resulta en una inestabilidad laboral, pero una flexibilidad política. A este hecho, Löwy, tras las huellas de Weber y Mannheim, llamará las "fluctuaciones y movimientos diversos" (1978, p. 17) del intelectual en la sociedad burguesa moderna:

La flotación de los intelectuales, como la de los globos de aires caliente en la noche de San Juan, es un estado provisional: generalmente terminan por ceder a la ley de gravedad y por dejarse atraer por una de las grandes clases sociales en lucha (burguesía, proletariado, a veces campesinado) o en todo caso por la clase que le es más cercana: la pequeña burguesía (Löwy, 1978, p. 18).

El intelectual afro también vive este proceso. No sabe si quedarse con la cultura hegemónica o si plegarse a los círculos intelectuales alejados del mundo urbano: universidades, revistas, periódico, política, escritura, etc. En cuanto a Abdias do Nascimento y Manuel Zapata Olivella se puede ver que ellos hicieron dos tránsitos en la sociedad, es decir, participaron de la vida política en sus países. En efecto, el intelectual siempre tiende a aproximarse a un grupo social. Por lo tanto, como afirma Mannheim, "[1]a posición social del grupo a la que los portadores de la síntesis [posición política] están afiliados determina ampliamente cuál de estas alternativas ha de ser destacada" (1973, p. 154). Es importante entender que las ideas del sociólogo húngaro es una defensa de las ideologías, de las visiones de mundo que no son derivaciones de la relación del sujeto con su conciencia, sino del grupo social con su medio cultural.

De manera general, el intelectual es aquel que interpreta de forma privilegiada los conflictos entres variadas visiones de mundo. Tanto Abdias do Nasciemento como Manuel Zapata Olivella se ven intelectuales oriundos de un grupo social alejado del poder hegemónico y son atraídos por la cultura del grupo dominante, pero esta atracción es 
desvelada en sus acciones de insertar las voces heterogéneas de la comunidad afro en el proyecto de nación. En sus escrituras ellos interpretarán las culturas bantú y yoruba como aquellas que están en conflictos con la cultura hegemónica.

En suma, comprendemos y demostramos cómo estos dos intelectuales afrodescendientes - Abdias do Nascimento y Manuel Zapata Olivella - , dentro de su cultura, crean un nuevo orden de pensamiento, conectando tanto su pensamiento en actividades literarias, en específico la creación de la obra, y en las sociales, esto es, actuar en posición reivindicatoria y política a favor del grupo social, de su gente.

Así, es en el contexto de los intelectuales latinoamericanos de cuño eurocéntrico, el intelectual afro ocupa un lugar singular, porque configura una tradición que está en desacuerdo con el colonizador. Ellos van a tejer una escritura que busca la descolonización, utilizando la misma arma del colonizador para desmontar una tradición dominadora.

\section{La discursividad ancestral}

Los intelectuales Abidas do Nascimento y Manuel Zapata Olivella establecen la tradición yoruba y bantú como temática: 'o negro é o tema principal da literatura negra', afirma Octavio Ianni, que vê o sujeito afrodescendente não apenas no plano do indivíduo, mas como "universo humano, social, cultural e artístico de que se nutre essa literatura" (Duarte, 2012).

De esa manera, la escritura de Sortilégio II y Changó, el gran putas es vista bajo la idea no de un asunto racial sino como parte de un proceso creativo, escritural, es decir, la discusividad literaria. Proceso que empezó a existir cuando los afros aprendieron el idioma del esclavista y expresaron en ese idioma su crítica contra la cultura hegemónica. Las identidades afros fueran construidas en las fracturas originadas en el proceso de mestizaje. Tal proceso fue violento pues impuso al negro otra realidad, la cultura del colonizador. De ahí, si el escritor solamente utiliza la cuestión de una mezcla racial, no es suficiente para conformar una literatura afrodescendiente. Por el contrario de esta idea, para pensar la literatura afrolatina es necesario la "assunção de uma perspectiva e, mesmo, de uma visão de mundo identificada à história, à cultura, logo a toda problemática inerente à vida desse importante segmento da população" (Duarte, 2008). Para ello, el escritor afro utiliza 
otro meio en la construcción del texto, es justamente el lenguaje como elemento "fundado na constituição de uma discursividade específica, marcada pela expressão de ritmos e significados novos e, mesmo, de um vocabulário pertencente às práticas linguísticas oriundas de África e inseridas no processo transculturador" (Duarte, 2008).

En ese reto, la escrita de Abdias do Nascimento y Manuel Zapata Olivella se ubica como practicas simbólicas en que ellos escriben en lengua hegemónica pero la infringen con otros signos, a saber, elementos de la tradición yoruba y bantú. De ahí, podemos pensar, como afirma Eduardo Assis Duarte, que tal postura de los autores va a formar otro elemento importante en la escritura literaria de los intelectuales afros. Nos referimos a la "formação de um público leitor afrodescendente como fator de intencionalidade próprio a essa literatura e, portanto, ausente do projeto que nortearia a literatura brasileira em geral (Duarte, 2008).

Por lo anterior, hay una literatura afro que busca visibilidad y espacio que es construido a partir del discurso del intelectual afro como tradición literaria latinoamericana. En otros términos el sujeto afro se muestra, se requiere en la literatura en diálogos con otras representaciones identitarias. Él no utiliza una única voz, no una única individualidad, sino representa una multiplicidad de voces que se construyen en la sociedad. Otro tanto se puede decir que "[i]mpõe-se destacar, todavia, que nenhum desses elementos isolados propicia o pertencimento à Literatura Afro-brasileira, mas sim a sua interação. Isoladamente, tanto o tema, como a linguagem e, mesmo, a autoria, o ponto de vista, e até o direcionamento recepcional são insuficientes" (Duarte, 2008, p. 3). La escritura afrodescendente es un conjunto no homogéneo y sobre eso proponemos observarla bajo el punto de tensión en el sistema literario latinoamericano. De esa manera, tales postulaciones que aquí levantamos nada más es que la discusión en el contexto de la literatura latinoamericana de la búsqueda por [las identidades]" (Nitrini, 2010, p. 63).

Cabe pensar que las identidades afros, siempre numerosas y múltiples, fueron forjadas bajo la herencia de la colonización, es decir, aquí en las Américas, pero en tensión con los aportes ancestrales. En esta cuestión de identidad, por ejemplo, Manuel Zapata Olivella, como afirma Tilli (2005, p. 23), utiliza el lenguaje "as means of resisting cultural hegemony and imperial dominance". De esa manera, el escritor 
afro colombiano inserta en la cultura del dominador el léxico y la semántica yoruba y bantú como forma de minar el sistema alfabético europeo y al mismo tiempo reafirmar su idiosincrasia.

El modelo de literatura fue impuesto por el sujeto europeo. Ya sabemos que dominar el código escrito ya hace a uno "superior", "letrado" y "civilizado" (Vivas, 2009, p. 2). En el sistema de la escritura occidental la mirada hacia el otro, es decir, hacia el aborigen es una mirada con vistas a categorizarlo y en cuanto a su literatura suele "considerar esta literatura aborigen y a sus respectivos estudiosos como vasallos de la escritura alfabética, de sus esquemas de percepción del mundo y de sus modelos de pensamiento, provengan estos del cristianismo, del humanismo o de la antropología" (Vivas, 2009, p. 16).

Obviamente las tradiciones de los pueblos indígenas y de los africanos que pueblan hoy estas tierras no gozan de prestigio en la estética oficial, de ahí, acordando con que afirma Vivas - aclaro que el citado autor hace un análisis de las culturas aborígenes en Colombia -, los autores afros aquí estudiados son "[v]asallos porque dependen de ella y porque viven en permanente insurrección frente a ella" (2009, p. 16). Aunque hayan sido marginadas, las influencias de los pueblos autóctonos de América Latina no pasaron sin ser percibidas en la escritura literaria. Por ejemplo, la literatura de las naciones indígenas existe, está en su comunidad. Estas culturas superviven y están en constante lucha para preservar sus espacios y sus tradiciones ancestrales.

De hecho, el texto literario puede ayudarnos a pensar la ancestralidad inventada con fines políticos, observada como algo que está más allá de aprehender el mundo y reordenar la vida. En otros términos, es comprender el mundo como herencia de los ancestros que tiene un manantial de cultura. Sin duda, "a herença africana é vasta e complexa, nela se funde suas raizes, na história e no imaginário" (Oliveira, 2007, p. 273). Por esta razón, la ancestralidad aparece en las obras de los intelectuales afrolatinos como "um tecido produzido no tear africano: na trama do tear está o horizonte do espaço" (Oliveira, 2007, p. 245), sobre todo en el juego del linguaje. Por ello afirmamos que en la escritura de Abdias do Nascimento y de Manuel Zapata Olivella las tradiciones yoruba y bantú, sobre todo los aportes ancestrales, ganan un estatus de discursividad literaria. En otros términos, se habla en la lengua hegemónica, pero se teje en el telar africano, con estructuras de la oralidad. Eso es la propuesta política de la escritura de los escritores 
afrolatinos, puesto que, como ya citamos antes, estos intelectuales ven el afrodescendiente no en el "plano do indivíduo" (Duarte, 2008, p. 4) sino en un contexto social multiétnico. De ahí, la escritura de ellos reafirma la estética afrolatina en que tema, lenguaje, escritura y público van a abrir "espaço para a configuração do discurso literário afrodescendente em seus diversos matizes" (Duarte, 2008).

Por lo anterior, como señala la novela Changó, la voz narrativa y lírica invita a una representación a partir de danzas, voces y cuerpos todo reunido en la ritualidad del conocimiento que se reitera en el conjunto de tradiciones yoruba y bantú. “¡Acérquense!” (Zapata 188), como invita Zapata Olivella y así somos convidados a ver cómo se conforma la discursividad ancestral. Para ello, es necesario estar en comunidad para revivir la espiritualidad de la vida ancestral y por medio de la escritura los autores aquí estudiados construirán el espacio de la vivencia ancestral. En efecto, la construcción del texto con las tradiciones africanas es evidenciar para la sociedad que "[1]a escritura es la base del conflicto étnico-social" (Vivas, 2013, p. 26). Una vez que existe el conflicto, es necesario apropiarse de lo simbólico para desmontar la hegemonía de la cultura de corte eurocéntrico.

Desde el punto de vista de la cultura, la novela de Zapata Olivella es eco de la sabiduría que vino de África y florece toda la América como elemento constitutivo de la identidad negra. La obra del escritor colombiano está impregnada de la cultura africana que resurge en varios espacios de América Latina. Esto es posible observar cuando leemos, por ejemplo, los títulos de los capítulos del libro Changó, el gran putas: "La tierra de los ancestros"; "El muntu americano; La rebelión de los vodús"; "Simón Bolívar: Memoria del olvido"; "José Prudencio Padilla: Guerras ajenas que parecen nuestras"; "El Aleijadinho: Donde quiera que tus manos sin dedos dejen la huella de tu espíritu"; "José María Morelos: El llamado de los ancestros Olmecas"; estos títulos en principio nos dan idea de la manera como la ancestralidad se esparce en el Nuevo Mundo, a saber, que la escritura de Zapata puede comenzar en varios lugares de América, sobre todo cuando se piensa en el legado del corpus africano en la diáspora.

En efecto, podemos afirmar que esta postura es una manera de estar en contra un pensamiento colonizado. No hay duda que la escritura europea fue utilizada para someter a los pueblos aborígenes de aquí y a esclavizar los africanos, así "[1]a escritura alfabética es la condena del 
analfabeta formulada por anticipado y ratificada por el metal en su propio cuerpo" (Vivas, 2009, p. 29). Pero, la cultura aborigen es distinta por utilizar la "multiplicidad de plataformas y tecnologías comunicativas" (Vivas, 2009, p. 30). De ahí, las culturas tradicionales interaccionan con la realidad poniendo en igualdad varios lenguajes. Tal vez, la es idea de conocimiento de la tradición africana sea semejante a la visión de mundo del pueblo minika especialmente en cuanto al kirigaiai que son los canastos del conocimiento. Ellos "pueden ser concebidos como partos de la tierra, es decir, que su evolución y constitución son el resultado de la interacción entre el territorio y los seres que lo habitan y cultivan" (Vivas, 2013, p. 94). Todo ello es una manera de interpretar el mundo, a partir del idioma se puede proteger $\mathrm{y}$ expresar el territorio (Vivas, 2013).

Como ejemplo de lo que hemos planteado aquí, Zapata Olivella describe la llamada a la lucha del personaje Agnes Brown por la voz de los Ancestros y establece la discursividad literaria contraponiendo elementos culturales hegemónicos occidentales con tradiciones africanas:

¡Que el pasado de esclavitud no tenga por qué avergonzarlos! El muntu surge valiente, fortalecido de todas sus heridas. Busca tu trinchera en las cenizas de tus huesos. Experiencia eres de aquellos que te siguen, te esperaron y acompañarán en la fría noche de los tugurios (Zapata, 2010, p. 443).

Otro ejemplo para que comparemos es cuando Abdias do Nascimento teje su escritura con los cantos de la religión afrobrasileña:

Ponto de Exu

Meu Exu brincalhão

Está nas encruzilhadas

De Ogum companheiro-irmão

Me livra de atrapalhadas

Coro: Laroiê, Axé (1979, p. 121)

Lo que queremos demonstrar con los dos trechos arriba es la similitud que hay en la recreación del mundo africano en América: Agnes Brown es protestante que escucha la voz Ancestral y emprende una lucha por la libertad y derechos civiles de los negros estadounidenses, pero antes se religa con su ancestralidad africana. Emanuel está en un espacio de culto que era suyo y después lo rechaza. La discursividad literaria de la ancestralidad se da en juntar cultura, jugar con ella: protestantismo y creencias tradicionales, lo que en la 
lógica Norteamericana no es posible. Lo mismo ocurre en subvertir el lenguaje con otros signos que no son de la cultura hegemónica. Los cantos para Exu - divinidad de la comunicación, aquél que guarda los caminos y está más allá del bien y del mal - ya no son cantados en lenguas africanas, ahora son cantados en lengua occidental, la lengua del colonizador. Hay también una subversión del lenguaje, por ejemplo, en la lengua portuguesa no se permite inicio de frase con pronombre complemento. Nascimento escribe: "Me livra", cuando la regla es "Livrame", a saber, hay una subversión sintáctica. Igualmente, Zapata Olivella inserta el vocablo "muntu" de origen lingüístico bantú, en otros términos, hay una subversión lexical. Por lo tanto, estos intelectuales se posicionan como insurrectos, como conscientes de las voces heterogéneas que habitan el mundo afrolatino y ponen estas voces como parte estética de sus textos. Los elementos de origen afro, el lenguaje, las estructuras narrativas son construcciones discursivas "marcada pela finalidade estética" (Assis 6) que los escritores inventan como delito en la escritura.

Así, la discursividad literaria de la ancestralidad yoruba y bantú es, indudablemente, una posición en contra de un orden hegemónico que parte, sin embargo, de las mismas fuentes eurocéntricas. Tanto Abdias do Nascimento como Manuel Zapata Olivella performatizan su texto, toman una posición política de cuño occidental para recuperar sus condiciones étnicas. De hecho, sus obras están colmadas de una escritura transgresora, a veces imperceptible. Los autores afros se apropian de la cultura escrita del grupo hegemónico - la escritura alfabética y discursos dominantes - y la deshacen, sutilmente, insertando otros elementos, yoruba y bantú, no aceptados por una orden estético vigente. La escritura afro en este sentido se plantea como un delito, es decir, una violación de lo establecido como normal y oficial.

\section{Conclusiones}

A partir de lo que expusimos hasta aquí, se puede decir que se hace relevante, en el marco de los estudios literarios y sus múltiples facetas, traer al espacio académico la recreación del pensamiento yoruba y bantú que proponen los intelectuales afrodescendientes: Abdias do Nascimento y Manuel Zapata Olivella. ¿Cómo piensan su mundo circundante, a partir de las culturas africanas? ¿Cuáles elementos o 
huellas de africanidad conforman la escritura literaria de Sortilégio II y Changó, el gran putas?

El aspecto político e histórico es una de las tantas posibilidades de lectura de la obra de Zapata Olivella. Tenemos en cuenta "la consciencia de que estamos hablando de una práctica social y, por lo tanto, estamos afrontando una construcción epistemológica que, como tal, niega su reificación" (Valero, 2013, p. 28). El autor colombiano pone en evidencia otros saberes en la construcción de la sociedad de Latinoamérica. De esa manera, no queremos crear un camino único para entender el "afro" en la literatura latinoamericana sino que entendamos tal concepto como un pensamiento plurivocal, es decir, la literatura afrolatina aquí está en el espacio de construcción de otra episteme, está poniendo en evidencia los discursos afros en la estética literaria.

Cabe comentar que las literaturas afros también son heterogéneas no sólo en relación con lo eurocéntrico, sino en relación con sus pares africanas, con sus pares caribeña, chocoanas, bahianas, entre otras. En verdad, existe un pluricentrismo, es decir, múltiples discursividades (Duarte, 2008), de las literaturas afros en América y en África. De ese conjunto, Nascimento y Zapata representan dos posibilidades de la discursividad ancestral. De esa manera, los textos de autores negros comunican experiencias, valores y situaciones individuales y colectivas bajo una estética que fue creada a partir de circunstancias, muchas veces deshumana y adversa. Es importante pensar también en un espacio donde el color de la piel no sea más importante que el texto literario, es decir, hay que pensar la literatura como "discursividade e a cor da pele ganhará importância enquanto tradução textual de uma história coletiva e/ou individual" (Duarte, 2008, p. 4). En otros términos, traducción textual quiere decir que cada individuo afro propone su forma de enunciar una experiencia que es diversa según haya sido su relación con los mundos heterogéneos americanos.

Por lo anterior, para que una literatura manifieste la heterogeneidad cultural debe ser transgresora en sus formas, es decir, en tales formas nuevas o antiguas se puede rastrear la huella de la ancestralidad y su función política. A partir de eso, bajo lo que plantea Silviano Santiago (1982), vemos que nuestra literatura latinoamericana ya instituyó su lugar en el mapa de la civilización occidental por intermedio del desvío de la normatividad, de una actividad destruidora. En estos trópicos, el escritor, de manera antropofágica, hace su literatura a partir de lo que 
los europeos enviaron para el Nuevo Mundo, cambiando y escribiendo a su modo. Así "falar, escrever, significa; falar contra, escrever contra" (Santiago, 1982, p. 16). Esto es el reverso de la imposición europea, pues "la escritura alfabética impuso sobre las culturas aborígenes de América la esclavitud" (Vivas, 2009, p. 22). El texto literario, en esta discusión, es un espacio de rescritura de varias tradiciones donde la trasgresión es la fuerza motriz creadora. Así, la escritura de la ancestralidad afro en obras literarias modernas de la tradición latinoamericana se caracteriza por su función política.

En conclusión, si al africano le arrancaron su cultura, su lengua, esto no quiere decir que lo haya perdido todo; quiere decir que él se vio obligado a apropiarse de la cultura del agresor para transformarla, dinamitarla y, luego, enriquecerla con los restos de africanidad que conservaba en su memoria, en su música, en su religiosidad. Por estas razones la escritura de Manuel Zapata Olivella y Abdias do Nascimento posee al mismo tiempo elementos grafocéntricos europeos $y$ latinoamericanos, a la par de elementos rituales yoruba y bantú.

\section{Referências}

AGUIAR, Mario (2004). Edición crítica de Changó, el gran putas. v. 1. Medellín: Universidad de Antioquia.

ALZATE, Sandra (2008). La evolucion literaria de Manuel Zapata Olivella: testimonio, autobiografía y novela. Dissertation (Doctor of Philosophy) University of Cincinnati, Cincinnati. Disponível em: <http://goo.gl/glQMVB>.

DUARTE, Eduardo de Assis (2008). Literatura Afro-brasileira: um conceito em construção. Estudos de Literatura Brasileira Contemporânea, Brasília, n. 31, p. 11-23.

CAICEDO, Jose Antonio (2013). A manos alzada... Memoria escrita de la diáspora intelectual afrocolombiana. Popayán: Sentipensar.

CASTRO, Yeda Pessoa (s.d.). A influência das línguas africanas no português brasileiro. [S.l.]: [s.n.]. Disponível em: <http://goo.gl/unegJ4>.

CAVAlCANTI, Pedro Celso Uchoa. (Org.) (1976). Abdias do Nascimento. Memórias do Exílio. São Paulo: Livramento.

ESSLIN, Martin (1986). Uma antomia do drama. Rio de Janeiro: Zahar.

GARCES, José Luis (2001). Manuel Zapata Olivella, caminante de la literatura y cultura. Colombia: Ministerio de Cultura. 
LEWIS, Marvin (1985). La trayectoria novelística de Manuel Zapata Olivella: de la opresión a la liberación, en ensayos de literatura colombiana. Bogotá: Plaza \& Janés.

LÖWY, Michael (1978). Por una sociología de los intelectuales revolucionarios. México: Siglo XXI.

MANNHEIM, Karl (1973). Ideología y utopía. Introducción a la sociología del conocimiento. Madrid: Aguilar.

NASCIMENTO, Abdias (1979). Sortilégio II: mistério negro de Zumbi redivivo. Rio de Janeiro: Paz e Terra.

NASCIMENTO, Elisa (2004). L. Abdias do Nascimento 90 anos - Memória Viva. Rio de Janeiro: Ipeafro.

NITRINI, Sandra (2010). Literatura comparada. São Paulo: USP.

OLIVEIRA, Eduardo (2007). Filosofia da ancestralidade: corpo de mito na filosofia da educação brasileira. Curitiba: Popular.

REZENDE, Maria Alice de Carvalho (2008). Intelectuales negros en el Brasil del siglo XIX. In: ALTAMIRANO, C. Historia de los intelectuales en América Latina, I: La ciudad letrada, de la conquista al modernismo. Buenos Aires: Katz.

SANTIAGO, Silviano (1982). Vale quanto pesa: ensaios sobre questões políticoculturais. Rio de janeiro: Paz e Terra.

SCHIPPER, Mineke (1982). Oral tradition and african theatre. In: SCHIPPER, Mineke. Theatre and Society in Africa. Johannesburg: Ravan Press. Disponível em: <http://goo.gl/YMgxzk>.

SILVA, Rosemere Ferreira da (2010). Trajetórias de dois intelectuais negros brasileiros: Abdias Nascimento e Milton Santos. Tesis (Doutorado em Estudos Étnicos e Africanos) - Universidade Federal da Bahia, Salvador. Disponível em: <https://repositorio.ufba.br/ri/bitstream/ri/8585/1/Silva.pdf>.

TILLIS, A. D. (2005). Manuel Zapata Olivella and the "Darkening" of Latin American Literature. Saint Louis: University of Missouri Press.

VALERO, Silvia (2013). ¿De qué hablamos cuando hablamos de 'literatura afrocolombiana'? o los riesgos de las categorizaciones. Estudios de Literatura Colombiana, n. 32, p. 15-37.

VIVAS, Selnich (2009). Vasallos de la escritura alfabética: riesgo y posibilidad de la literatura aborigen. Estudios de Literatura Colombiana, n. 25, p. 15-34.

VIVAS, Selnich (2013). Ñuera uaido: la palabra dulce o el arte verbal minika. Devenires, v. XIV, n. 28, p. 89-120. 
ZAPATA, Manuel Olivella (2010). Changó el gran putas. Bogotá: Ministerio de Cultura.

ZWERLING, Philip (2004). The political agenda for theatricalizing religion in Shango de Ima and Sortilege II: Zumbi returns. Journal of Religion and Theatre, v. 3, n. 2, p. 303-16.

Recebido em maio de 2014.

Aprovado em setembro de 2014.

\section{resumo/abstract}

\section{Abdias do Nascimento y Manuel Zapata Olivella: intelectuales del siglo XX en el sendero de la discursividad ancestral yoruba y bantú}

\section{Denilson Lima Santos}

En este ensayo planteamos el texto literario como un espacio de re-escritura de las tradiciones yorubas y bantúes como fuerza motriz creadora de un discurso literario. Las voces africanas en las Américas aparecen recuperadas en un modelo estético diferente del hegemónico. Como ejemplo de eso, se propone describir las obras: Sortilégio II: mistério negro de Zumbi redivivo (1979), de Abdias do Nascimento (1914-2011), y Changó, el gran putas (1983), de Manuel Zapata Olivella (1920-2004). Los autores de estas obras, como intelectuales, se posicionan como insurrectos, como conscientes de las voces heterogéneas que habitan el mundo afrolatino y ponen esas voces como parte de la estética de sus textos. Así, los intelectuales afrolatinos proponen una escritura de la ancestralidad afro con propósitos estéticos y políticos en la tradición literaria latinoamericana.

Palavras-chave: escritura, tradiciones africanas, literatura, discursividad, ancestralidad.

\section{Abdias do Nascimemto \& Manuel Zapata Olivella: Intellectuals of the 20th century on the road to discursive knowledge of Ancestral Yoruba and Bantu}

\section{Denilson Lima Santos}

In this essay we propose the literary text as a space for the re-writing of Bantu's and Yoruba's traditions like a creative motor force of literary discourse. African voices in the Americas appear to regain power in a different, aesthetic, hegemonic model. An example of this can be seen in the literary works: Abdias 
do Nascimento's (1914-2011) Sortilégio II: mistério negro de Zumbi redivivo (1979) and Manuel Zapata Olivella's (1920-2004) Changó, el gran putas (1983). The authors of these works, as intellectuals, position themselves as rebels, conscious of the heterogeneous voices that inhabit the Afro-Latin world and they give those voices a role in the aesthetics of their texts. Thus, these intellectuals propose an Afro-Latin writing of African ancestry with aesthetic and political purposes in the Latin American literary tradition.

Keywords: writing, african traditions, literature, discourse, ancestry. 